Brit. J. industr. Med., 1960, 17, 109.

\title{
PNEUMOCONIOSIS IN MAKERS OF ARTIFICIAL GRINDING WHEELS, INCLUDING A CASE OF CAPLAN'S SYNDROME*
}

BY

\author{
E. POSNER
}

\author{
From the Stoke-on-Trent Mass Radiography Centre
}

(RECEIVED FOR PUBLICATION NOVEMBER 3, 1959)

\begin{abstract}
Mass miniature radiography surveys in a factory producing artificial grinding wheels detected cases of pneumoconiosis, mostly of the silicotic type. All cases were traced to the department where the so-called "bond" is prepared and mixed with the abrasive grains of carborundum and artificial corundum. This ceramic-vitrified bond, similar in composition to English general earthenware, contained until recently a significant proportion of free silica.

The miniature film survey was followed up by an investigation on full-sized films, in which $92 \%$ of all workers in the bond department participated. The radiographs were subjected to dual independent viewing and it was found that $66 \%$ of the men who had worked in the bond department for more than 10 years showed radiological evidence of pneumoconiosis with a high proportion of progressive massive fibrosis (P.M.F.)

Recently the amount of free silica in the ceramic bond has been reduced by the introduction of "frits" in place of powdered flint and part of the factory has been rebuilt and new methods of dust suppression and dust extraction have been introduced. One of the cases presented with the rheumatoid-pneumoconiotic syndrome, first described by Caplan.

It is suggested that some of the cases of pneumoconiosis, attributed to carborundum, may be due to the binding materials of artificial grinding wheels.
\end{abstract}

Pneumoconiosis in Users of Grinding Wheels

Until the third decade of this century the mortality rates of cutlery and metal grinders generally, and particularly those from tuberculosis, interstitial pneumonia, and other respiratory disease, ranked among the highest of all occupational groups. Between 1880 and 1910, for instance, the comparative mortality figures for "phthisis" in grinders averaged 450 (Registrar General, 1908, 1914) and in 1921 the standardized mortality rate from tuberculosis in metal grinders was 1,200 and that for all other respiratory disease 640 (Britten, 1928). Thus, almost 100 years after Holland (1843) had stated that "fork grinding is the most destructive occupation to human life", silicosis and tuberculosis still killed many highly skilled craftsmen in the prime of life. By 1931 the standardized mortality rate for tuberculosis in grinders had fallen to 275 (Registrar General, 1936), but investigations by Turner and Martin (1949) in Sheffield and by

* Based on a paper read to the annual meeting of the British Tuberculosis Association at Cambridge, July, 1959.
Meiklejohn (1949) in the Black Country provided further evidence of the high morbidity and mortality from respiratory disease in metal and cutlery grinders, who used natural sandstone wheels.

For the past 20 years, however, the number of deaths from silicosis and tuberculosis in grinders has been steadily falling (Chief Inspector of Factories, 1927-57) and the reports of the Ministry of National Insurance (1952-57) show now only an average of six new cases each year.

This remarkable change is due to the substitution of artificial grinding tools for natural sandstone wheels (Hunter, 1955).

New artificial abrasives were invented in the United States towards the end of the last century and have replaced sandstone for grinding processes since the end of the first world war on an increasing scale. In 1926, for instance, there were still 1,600 sandstone wheels in Sheffield, in 1933 only 200 (Chief Inspector of Factories, 1936).

The most commonly used artificial abrasives in grinding wheels are carborundum (silicon carbide) 
and corundum (aluminium oxide). Artificial corundum has been a problem in occupational medicine since the last war, as its manufacture produced extensive pulmonary fibrosis, emphysema, and spontaneous pneumothorax, a syndrome now well known as "Shaver's disease" (Shaver and Riddell, 1947; Riddell and Shaver, 1948; Jephcott, 1948; Goralewski, 1939, 1940) On the other hand, there is no definite evidence that grinding wheels containing corundum are harmful to workers who use them in a large variety of processes.

The question of the fibrogenetic properties of carborundum is more controversial. Gardner (1923) showed that it was not toxic to animals, but his later experiments (Gardner, 1938) suggested that silicon carbide together with tuberculous infection can produce a fibrotic pulmonary reaction in animals. Bruusgaard (1949 and 1953), Bruce (1942), and Smith and Perina (1948) reported radiological nodulation in the films of workers exposed to carborundum dusts for long periods, whereas Miller and Sayers (1934) and Clark and Simmons (1925) placed it in the group of inert dusts.

The hardness of the artificial abrasives, however, approaches that of diamonds and consequently their introduction caused a very significant reduction of dust at grinding operations, compared with natural sandstone (Bergerhoff, 1937).

The statement of the Chief Inspector of Factories (1928), therefore, that "the substitution of carborundum wheels for old time sandstone expedites the elimination of a widespread occupational disease from the metal industry", and Hunter's forecast (1955) that by 1975 there should not be any more cases of pneumoconiosis in metal grinders, are at present well supported by statistical evidence and common experience.

\section{Pneumoconiosis in Makers of Grinding Wheels}

In contrast to the extensive literature concerning the risks by the users of artificial carborundum wheels, very little has been published about the dangers to the men who produce them. The results of a series of mass radiography surveys in a large factory manufacturing artificial grinding wheels may, therefore, be of some interest.
At the first survey in 1953, nine patients with pneumoconiosis were detected in the factory, five of whom had P.M.F. or pneumoconiosis complicated by tuberculosis. Of the nine men, one could have acquired the condition during previous work as a coal-miner, and one man had always worked on the kilns for firing abrasive wheels. The remaining seven were either working or had previously been employed in one and the same workshop, and otherwise had no exposure to industrial dusts during their working life. It was therefore decided to radiograph the workers in that part of the factory, the bond preparing and mixing department, and those previously associated with it, on full-sized films at the next survey in 1955 . The response was satisfactory; 47 of the 51 eligible men attended $(92 \%)$. Five men, who had previously worked in mines or the pottery industry, were omitted from the investigation.

The remaining 42 films were read independently by Drs. Cochrane and Miall, of the Pneumoconiosis Research Unit at Cardiff, and by myself. The results in condensed form are shown in Table 1.

TABLE 1

RESULT OF INDEPENDENT VIEWING OF FILMS OF ABRASIVE BOND WORKERS

\begin{tabular}{l|c|c}
\hline & $\begin{array}{c}\text { Observers } \\
\text { C. and M. } \\
\text { (Cardiff) }\end{array}$ & $\begin{array}{c}\text { Observer } \\
\text { P. } \\
\text { (Stoke) }\end{array}$ \\
\hline $\begin{array}{l}\text { Category 0 (no pneumoconiosis) } \\
\begin{array}{l}\text { Categories 1/-/-/, 2/-/-1,3/-1-1 } \\
\text { (simple pneumoconiosis) }\end{array}\end{array}$ & 25 & 26 \\
Categories A-C (PMF) & 11 & 10 \\
\hline Total & 6 & 6 \\
\hline
\end{tabular}

There was almost full agreement with regard to diagnosis, and full agreement about the presence of P.M.F. In those cases where the observers disagreed about the radiological stage of simple pneumoconiosis, the readings of the Cardiff observers were used for Table 2, which shows that the incidence of radiologically manifest pneumoconiosis in men employed in the bond department for more than 10 years was high. The considerable proportion of cases with P.M.F. (six out of 17 cases) seemed to be particularly noteworthy.

TABLE 2

PNEUMOCONIOSIS IN ABRASIVE BOND WORKERS

\begin{tabular}{|c|c|c|c|c|c|c|c|c|c|}
\hline $\begin{array}{c}\text { Length of } \\
\text { Occupational Risk }\end{array}$ & $\begin{array}{l}\text { Radio- } \\
\text { graphed }\end{array}$ & $\mathbf{0}$ & $1 /-|-|$ & $2 /-/-1$ & $3 /-1-1$ & $\mathbf{A}$ & B & $\mathbf{C}$ & $\%$ Pneumoconiosis \\
\hline $\begin{array}{l}\text { Less than } 5 \text { years } \\
5-10 \text { years } \\
11-15 \text { years } \\
\text { More than } 15 \text { years }\end{array}$ & $\begin{array}{r}13 \\
8 \\
7 \\
14\end{array}$ & $\begin{array}{r}13 \\
5 \\
2 \\
5\end{array}$ & $\begin{array}{l}\overline{2} \\
1 \\
1\end{array}$ & $\begin{array}{l}\overline{1} \\
2 \\
3\end{array}$ & $\bar{z}$ & $\overline{-}$ & $\bar{z}$ & $\frac{-}{1}$ & $\left.\begin{array}{l}37 \cdot 5 \\
71 \cdot 4 \\
64 \cdot 3\end{array}\right\} 66 \cdot 6$ \\
\hline Total & 42 & 25 & 4 & 6 & 1 & 3 & 2 & 1 & $40 \cdot 5$ \\
\hline
\end{tabular}


The nodular lesions on the films were mostly of the silicotic type and also the massive shadows were those commonly seen in classical silicosis. A small number of films, however, showed the appearances described in cases of "mixed dust pneumoconiosis" with smaller, less well-defined lesions of oval, round, or irregular shape.

Five men, whose films showed category $1 /-/-/$ or $2 /-/-/$ simple pneumoconiosis, were practically symptom free, the other workers complained either of one, or of a combination of such symptoms as tightness in the chest, dyspnoea on exertion, dry or productive cough, lassitude, anorexia.

Two of the men have since died and classical silicosis with P.M.F. was found at necropsy.

The following are two illustrative case histories:-

Case 1.-This man was 52 years old when first seen in 1953. He worked as a shoemaker for seven years and as a plasterer in the building trade for 17 years. For the past 15 years he had been employed in the bond preparing and bond mixing department of the abrasive wheel factory. $\mathrm{He}$ had complained of increasing dyspnoea for the past five years, of cough with little expectoration, of lassitude, and of anorexia. Sputum was repeatedly negative for acid-fast bacilli on smear and culture. A radiograph showed silicotic nodular shadowing in both lungs with large non-homogeneous shadows in both infraclavicular fields (Fig. 1).

His disability was originally assessed as $50 \%$ but his health deteriorated rapidly in the course of 12 months, after which he worked only occasionally and for short

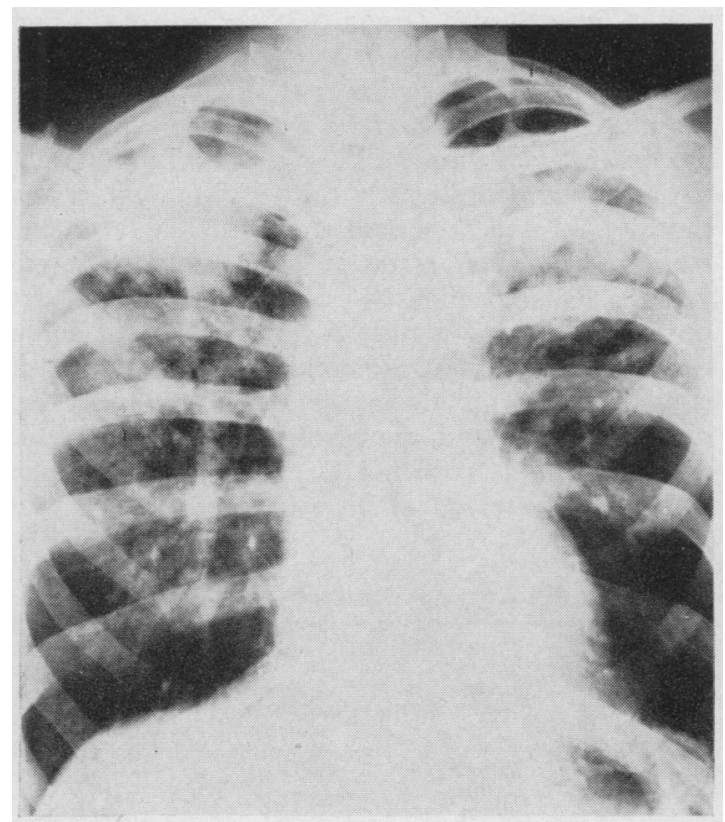

FIG. 1 periods. Dyspnoea became increasingly severe and confined him to bed after 19 months from his attendance at the $x$-ray unit. He had occasional small haemoptyses and died in December, 1955.

At necropsy both upper lobes and the right middle lobe were found to be filled by fibrous, firm, greyish tissues of rubbery consistency, gritty under the knife, and containing necrotic areas. The remaining lobes contained numerous greyish fibrotic lesions. There was marked hypertrophy of the right cardiac ventricle and auricle. The cause of death was right-sided cardiac failure and silicosis.

Case 2.-This man was 47 years old when first seen at the M.M.R. unit in 1955 . He had worked as a general labourer in non-dusty trades for 14 years and had been employed in the bond department of the abrasive wheel factory for $\mathbf{1 8}$ years. He complained of productive cough and moderate dyspnoea on exertion. Apart from signs of chronic bronchitis, there were no abnormal clinical findings. Sputum was repeatedly negative for acid-fast bacilli. A radiograph (Fig. 2) showed nodular shadows in both upper and the right middle lung fields with a triangular massive shadow in the right upper field. In the left lung there were a few larger, oval, ill-defined opacities of a diameter approximately $1 \mathrm{~cm}$.

When next seen two years later these oval shadows had become more numerous in the left lung and had also appeared in the right lung (Fig. 3). The man had remained fairly fit, but dyspnoea had become slightly more severe and he now complained of pains in the phalangeal joints of both hands and of the right foot and in the right hip. $\mathrm{He}$ had developed fusiform

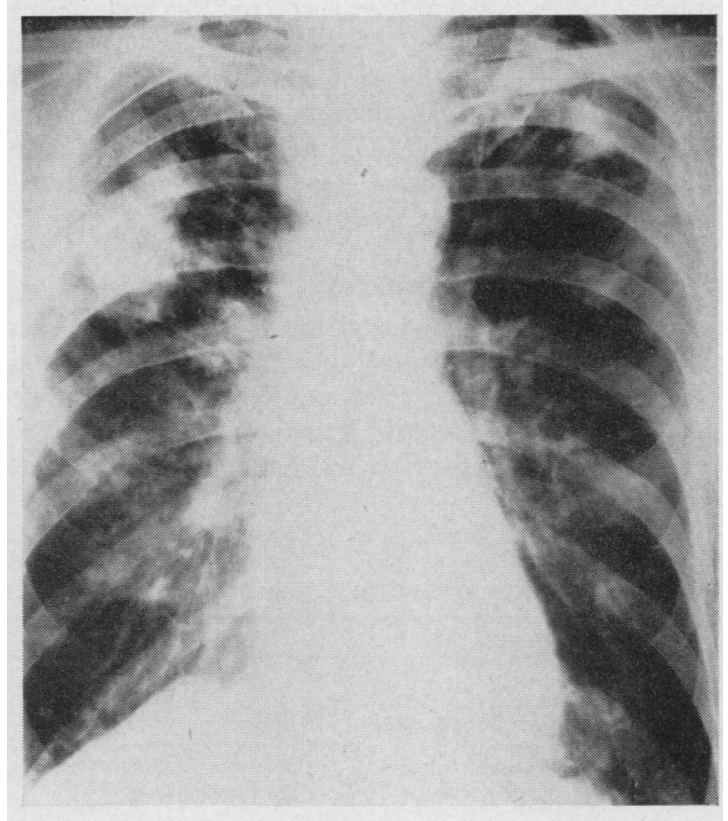

FIG. 2 


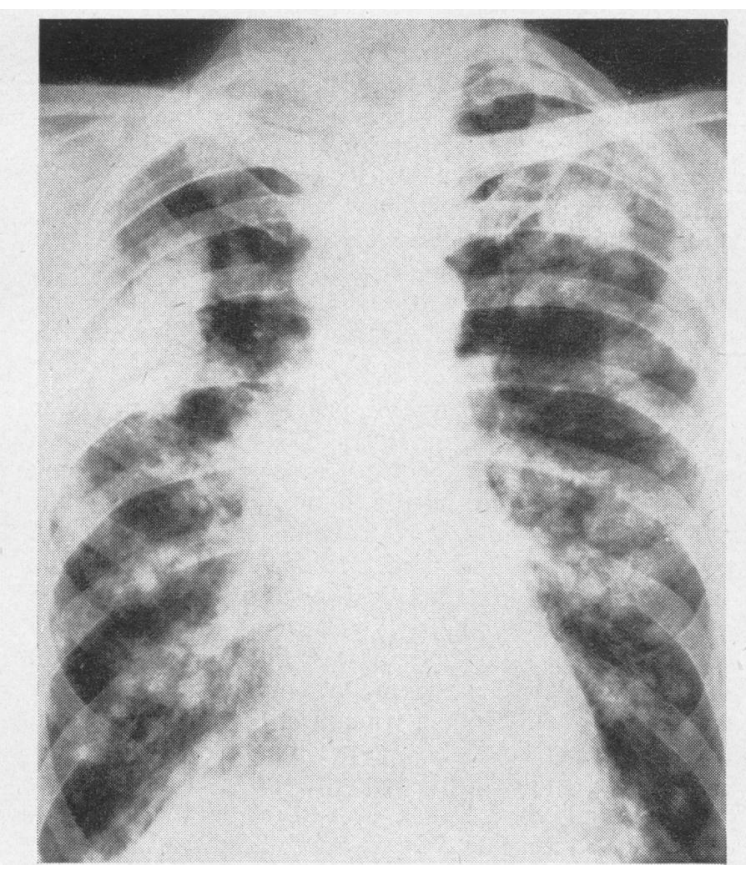

Fig. 3

swellings of the phalangeal joints of both hands. The films and case history were shown to Dr. Caplan, who wrote "the second film of the man is quite typical of the rheumatoid syndrome; the characteristic change is well shown. I think I would have suspected this even on his previous film."

This case is considered to be a further addition to the cases of the rheumatoid-pneumoconiotic syndrome (Caplan, 1953) in non-miners. The literature of these cases has recently been summarized by Caplan, Cowen, and Gough (1958).

\section{The Bond of Artificial Grinding Wheels}

"Bond" is the term used for the material which holds the abrasive grains together in the grinding wheel and supports them while they cut. The hardness of each wheel is largely determined by the resistance the bond offers against the tearing off of the abrasive.
Synthetic resins, rubber, and other organic materials are now being used on an increasing scale, but the traditional and still most commonly used bond is a ceramic vitrified one, and its components are very similar to those used for the manufacture of general earthenware in North Staffordshire (Table 3). The nature and proportion of ceramic bonding materials vary from factory to factory and are usually a well-guarded trade secret. The samples shown in Table 3, however, have been chosen from modern technical publications (Houchins, 1957; Teague, Brown, Emmett, Lawrence, and Sutcliffe, 1946; Rosenthal, 1949) and are thought to be representative.

Flint is almost pure free silica and was used in the factory as a finely ground powder not only as a part of bonding materials, but also for supporting the wheels during kiln firing. As in the china industry, (Meiklejohn and Posner, 1957) this method was replaced by bedding into alumina in 1937 . In recent years, flint as a component of the ceramic bond has also been largely replaced by so-called "frit", a mixture consisting mostly of silicates and oxides, and also widely used in the glass industry and for glazing pottery. The free silica content of frits is far below that of flint or quartz, but cases of pneumoconiosis in men exposed to dry pottery glazes have been reported (Jones, 1951). It is also noteworthy that the type of felspar commonly used for ceramic purposes in this country, so-called "Cornish stone", contains $30-35 \%$, and ball clays from Cornwall and Devon $5-25 \%$ free silica (Factory Inspectorate, 1959). Nevertheless the substitution of a material consisting almost entirely of free silica, such as flint, by frits, is likely to reduce the risk from pneumoconiosis in bonding processes. Even more important are the very impressive and thorough changes in dust prevention and general workshop hygiene made in the factory in recent years. The shovelling and manual handling of dry powders has now almost entirely ceased, and has been replaced by an ingenious system of automatic conveying and mixing in enclosed pipes and cylinders. Accurate and comparable dust counts of the past and present are not available, but the times when, in the words of an eye witness, "flint was

TABLE 3

SAMPLES OF VITRIFIED BOND FOR ARTIFICIAL GRINDING WHEELS AND OF GENERAL EARTHENWARE

\begin{tabular}{|c|c|c|c|c|c|}
\hline I & $\begin{array}{l}\text { Felspar } \\
\text { Ball clay } \\
\text { Flint } \\
\text { Kaolin } \\
\text { Whiting (chalk) }\end{array}$ & $\begin{array}{l}70 \% \\
10 \% \\
10 \% \\
9 \% \\
1 \%\end{array}$ & II & $\begin{array}{l}\text { Felspar } \\
\text { Ball clay } \\
\text { Silica } \\
\text { Calcite (Calcium carbonate) }\end{array}$ & $\begin{array}{l}38 \% \\
19 \% \\
26 \% \\
17 \%\end{array}$ \\
\hline III & $\begin{array}{l}\text { Felspar } \\
\text { Clay } \\
\text { Frit }\end{array}$ & $\begin{array}{l}60 \text { parts } \\
40 \text { parts } \\
25 \text { parts }\end{array}$ & $\begin{array}{l}\text { General } \\
\text { Earthenware }\end{array}$ & $\begin{array}{l}\text { Ball clay } \\
\text { Kaolin } \\
\text { Flint } \\
\text { Cornish stone (felspar and quartz) }\end{array}$ & $\begin{array}{r}18-47 \% \\
24-37 \% \\
21-38 \% \\
7-15 \%\end{array}$ \\
\hline
\end{tabular}


brought into the factory in wagon loads and shovelled on a concrete floor", have certainly passed.

\section{Discussion and Conclusions}

Pneumoconiosis in makers of artificial grinding wheels, more specially in abrasive bond preparers, has in the past attracted little attention, although Middleton (1953) referred to the silica content of the bonded wheel at the Third International Conference on Pneumoconiosis in Sydney, and Italian and German authors (de Dominicis, 1947; Schmidt, 1954; Schneider, 1957) mentioned it in the context of general communications on silicosis. Its occurrence is an example of the not uncommon experience that industrial inventions, of great benefit to the users of new tools, create new and for some time hidden hazards to those who provide them. However, the introduction of new bonding materials containing less free silica and improved dust prevention are likely to reduce the problem of pneumoconiosis in abrasive bond workers to a similar extent as did the substitution of flint by alumina in the china industry (Meiklejohn and Posner, 1957).

It is reassuring that, in the factory under review, since 1955 only one further case of simple pneumoconiosis has been found in bond workers at two further surveys, and that none of the previously detected cases with simple pneumoconiosis has since developed P.M.F.

On the other hand, the silica content of the bonded ceramic wheel must be considered in cases of pulmonary fibrosis, occasionally attributed to carborundum. Both quartz and flint are converted to the crystalline forms of trydimite and cristobalite at the high temperatures at which wheels are fired in kilns, and both these substances are known to cause a more rapidly developing silicosis in animals than quartz or fused silica (King, Mohanty, Harrison, and Nagelschmidt, 1953). Despite the hardness of artificial grinding wheels, some dust is given out in grinding operations, and the problem of the cause of pneumoconiosis in workers using carborundum wheels, is, as Middleton (1953) stated, worth further detailed investigation.

I am indebted to the managers of the factory for their help with the investigation and for valuable criticisms of the technical aspects of this paper. I am grateful to Dr. A. L. Cochrane and Dr. W. E. Miall, of the Pneumoconiosis Research Unit, for their assessment of the films, to Dr. F. Pick, of the Stafford Infirmary, for pathological reports, and to Dr. L. Bowcock for the reproduction of radiographs. I wish to thank Miss A. Holdsworth for clerical assistance.

\section{REFERENCES}

Bergerhoff, W. (1937). Arch. Gewerbepath. Gewerbehyg., 8, 339. Britten, R. H. (1928). Publ. Hlth Rep. (Wash.), 43, 1565

Bruce, T. (1942). "Die Silikose als Berufskrankheit in Schweden, p. 113. Acta med. scand., Suppl. 129.

Bruusgaard, A. (1949). Proc. Ninth Int. Conf. Industr. Med., London, 1948, pp. 676-680.

1953). Proc. Third Int. Conf. of Experts on Pneumoconiosis, Sydney, 1950. Record of Proceedings, Vol. 1, p. 19.

Caplan, A. (1953). Thorax, 8, 29.

Cowen, E. D. H., and Gough, J. (1958). Ibid., 13, 181.

Chief Inspector of Factories (1927-1957). Annual Reports.

H.M.S.O., London. H.M.S.O., London.

1936). Annual Report for the Year 1935, Cmd. 5230, p. 58. H.M.S.O., London.

Clark, I. W.. and Simmons, E. B. (1925). J. industr. Hyg., 7, 345.

Dominicis, G̈. de (1947). Med. d. Lavoro, 38, 122.

Factory Inspectorate (1959). A Survey of the Pottery Industry in Stoke-on-Trent. H.M.S.O., London.

Gardner, L. U. (1923). Amer. Rev. Tuberc., 7, 344.

(1938). In Lanza, A. J. Silicosis and Asbestosis. Oxford University Press, London.

Goralewski, G. (1939). Arch. Gewerbepath. Gewerbehyg., 9, 676.

Goralewski, G. (1939). Arch.

Holland, G. C. (1843). The Vital Statistics of Sheffield. Tyas, London. (Quoted by Hunter, D., 1955.)

Houchins, H. R. (1957). Ceramic Age, 69, January, p. 12.

Hunter, D. (1955). The Diseases of Occupations, p. 852. English Universities Press, London.

Jephcott, C. M. (1948). Occup. Med., 5, 701.

Jones, W. W. (1951). Tuberculosis in Industry. N.A.P.T., London.

King, E. J., Mohanty, G. P., Harrison, C. V., and Nagelschmidt, G. (1953). Brit. J. industr. Med., 10, 9.

Meiklejohn, A. (1949). Ibid., 6, 241.

Meiklejohn, A. (1949) (16id., 6, 241 i4, 229.

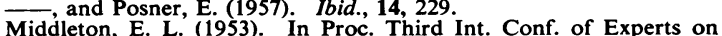
Pneumoconiosis, Sydney, 1950, Vol. 1, p. 312 . I.L.O., Geneva. Miller, J. W., and Sayers, R. U. (1934). Publ. Hlth Rep. (Wash.), 48, 19 .

Ministry of National Insurance (1952-1957). Annual Reports. H.M.S.O., London.

Registrar-General (1908). Supplement to the 65th Annual Report, England and Wales. H.M.S.O., London.

(1914). Supplement to the 75th Ännual Report, England and Wales. H.M.S.O., London.

(1936). Decennial Supplement England and Wales. H.M.S.O., London.

Riddell, A. R. and Shaver, C. G. (1948). Occup. Med., 5, 710.

Riddell, A. R., and Shaver, C. G. (1948). Occup. Med., 5, 710.
Rosenthal, E. (1949). Pottery and Ceramics. Penguin Books, Harmondsworth, Mddx.

Schmidt, K. G. (1954). Ber. disch. keram. Ges., 31, 355.

Schneider, H. (1957). Personal communication.

Shaver, C. G., and Riddell, A. R. (1947). J. industr. Hyg., 29, 145.

Smith, R. A., and Perina, A. E. (1948). Occup. Med., 5, 396.

Teague, E. D.. Brown, A., Emmett, H., Lawrence, J., and Sutcliffe, M. S. (1946). "Grinding Wheel Manufacture in Germany"' British Intelligence Objectives Sub-Committee Final Report No. 1407 [Item No. 21.] H.M.S.O. London.

No. 1407 [Item No. 21.] H.M. M.S.O., London.
Turner, H. M., and Martin, W. J. (1949). Brit. med. J., 2, 1148. 